\title{
The phylogenetic significance of vestured pits in Boraginaceae
}

\author{
David Rabaey, ${ }^{1}$ Frederic Lens, ${ }^{1}$ Erik Smets ${ }^{1,2}$ \& Steven Jansen ${ }^{3,4}$ \\ 1 Laboratory of Plant Systematics, Institute of Botany and Microbiology, Kasteelpark Arenberg 31, P.O. Box 2437, 3001 Leuven, Belgium \\ 2 Netherlands Centre for Biodiversity Naturalis (section NHN), Leiden University, P.O.Box 9514, 2300 RA Leiden, The Netherlands \\ 3 Jodrell Laboratory, Royal Botanic Gardens, Kew, TW9 3DS, Richmond, Surrey, U.K. \\ 4 Institute of Systematic Botany and Ecology, Ulm University, Albert-Einstein-Allee 11, 89081, Ulm, Germany \\ Author for correspondence: David Rabaey,david.rabaey@bio.kuleuven.be
}

\begin{abstract}
The bordered pit structure in tracheary elements of 105 Boraginaceae species is studied using scanning electron microscopy to examine the systematic distribution of vestured pits. Forty-three species out of 16 genera show a uniform presence of this feature throughout their secondary xylem. Most vestures are small, unbranched and associated with the outer pit aperture of bordered intervessel pits. The feature is likely to have originated independently in the distantly related subfamilies Boraginoideae (tribe Lithospermeae) and Ehretioideae. The distribution of vestures in Ehretia agrees with recent molecular phylogenies: (1) species with vestured pits characterise the Ehretia I group (incl. Rotula), and (2) species with non-vestured pits belong to the Ehretia II group (incl. Carmona). The occurrence of vestured pits in Hydrolea provides additional support for excluding this genus from Hydrophylloideae, since Hydrolea is the only species of this subfamily with vestured pits. Functional advantages of vestured pits promoting parallel evolution of this conservative feature are suggested. The hydraulic benefits of poorly developed vestures remain underinvestigated.
\end{abstract}

Keywords Boraginaceae; Boraginoideae; bordered pit; Ehretioideae; scanning electron microscopy; vestures

\section{口INTRODUCTION}

Vestures are small protuberances from the secondary cell wall, which are mainly associated with the pit chamber of bordered pits in tracheary elements of vessel-bearing plants (Bailey, 1933; Jansen \& al., 1998). In addition, vestures can be observed on the inner wall of vessels and on the rim of perforation plates. Although various authors have described different types of vestures based on scanning electron microscopy (SEM), the presence or absence of this feature appears much more interesting from a systematic point of view than analysing its micromorphological variation (Scurfield \& al., 1970; Ohtani \& Ishida, 1976; Van Vliet, 1978; Nair \& Mohan Ram, 1989; Jansen \& al., 1998, 2001). It has been demonstrated that the distribution of vestured pits is consistent with large monophyletic angiosperm clades such as Myrtales, Gentianales, and most Legumes (Herendeen, 2000; Jansen \& Smets, 2000; Jansen \& al., 2008; Lens \& al., 2008). Accordingly, this character is one of the most interesting wood anatomical characters showing a great phylogenetic significance at higher taxonomic levels such as (sub)families and orders. Depending on the taxonomic group, vestured pits have also proven to be valuable at the genus level, for instance in Phyllanthaceae, Proteaceae, and Solanaceae (Jansen \& al., 2001).

Boraginaceae is a subcosmopolitan family and comprises about 2450 species in 142 genera (Mabberley, 2008). For a long time, the phylogenetic relationships within Boraginaceae were debated, although five subfamilies were traditionally recognised: Boraginoideae, Cordioideae, Ehretioideae, Heliotropioideae, and Wellstedioideae (e.g., Gürke, 1893; Pilger, 1912; Johnston, 1950, 1951). Johnston (1950, 1951) considered the
Cordioideae and Ehretioideae as more "primitive" and Boraginoideae and Heliotropioideae as more "derived" based on morphological data. Molecular phylogenies, however, revealed a completely different evolutionary scenario. These studies showed a newly circumscribed family Boraginaceae, including the Hydrophyllaceae and the parasitic Lennoaceae (APG, 1998, 2003; Ferguson, 1999; Langström \& Chase, 2002; Luebert \& Wen, 2008). The family remains unplaced at the base of the asterid I (APG, 1998, 2003). Gottschling \& al. (2001) hypothesized that the subfamily Boraginoideae is sister to five remaining subfamilies. Among these subfamilies, Hydrophylloideae is basal, followed by Heliotropoideae and Cordioideae, which is sister to Lennoideae and Ehretioideae (Fig. 1A). The position of Wellstedioideae remains uncertain since it has never been included in a molecular phylogeny. It has been suggested to be linked to Boraginoideae, although this needs to be confirmed (Stevens, 2001-). The position of Boraginoideae as sister to the rest of the family is well supported in other studies (Ferguson, 1999; Langström \& Chase, 2002; Moore \& Jansen, 2006; Luebert \& Wen, 2008). However, although primary woody borages (Heliotropoideae, Cordioideae, Lennoideae, Ehretioideae) form a monophyletic group characterized by a hard and multilayered endocarp, the relationships between the other subfamilies remain unclear (e.g., Ferguson, 1999; Langström $\&$ Chase, 2002; Moore \& Jansen, 2006; Luebert \& Wen, 2008). Furthermore, much more work needs to be done to clarify the generic boundaries of several taxa (e.g., Miller, 2003; Craven, 2005; Retief \& Van Wyk, 2005).

Despite the proven phylogenetic significance of vestured pits in various angiosperm clades, their distribution in Boraginaceae is unclear due to (1) the fragmentary screening of 
this feature in Boraginaceae (Table 1), and (2) the problematic intrafamily relationships. The objective of this study is to provide a detailed survey of the distribution of vestured pits in Boraginaceae and to evaluate the phylogenetic importance of this character based on current phylogenetic insights.

\section{MATERIALS AND METHODS}

Wood samples from 105 specimens were collected from the wood collections of Tervuren (Tw), Utrecht (Uw), Madison (MADw), The Smithsonian Institution (USw) and from the herbarium of National Botanical Garden of Belgium (BR). The species selected represent all major groups according to recent molecular phylogenies (APG, 1998, 2003; Gottschling \& al., 2001). Species of the former Lennoaceae, however, were not included due to lack of material. The species investigated are listed in Table S1 in the Electronic Supplement to this article with reference to their origin and collectors.

Small blocks $\left( \pm 3 \mathrm{~mm}^{2}\right)$ were cut with a razor blade, cleaned with household bleach to remove particles in the pit chamber that could be interpreted as "pseudo-vestures" (Exley $\&$ al., 1974; Gale, 1982) and attached to stubs using electronconductive carbon paste. The samples were sputter coated for 3 min with gold (Spi-Supplies, West Chester, Pennsylvania, U.S.A.). Observations were carried out using a Jeol JSM 6360
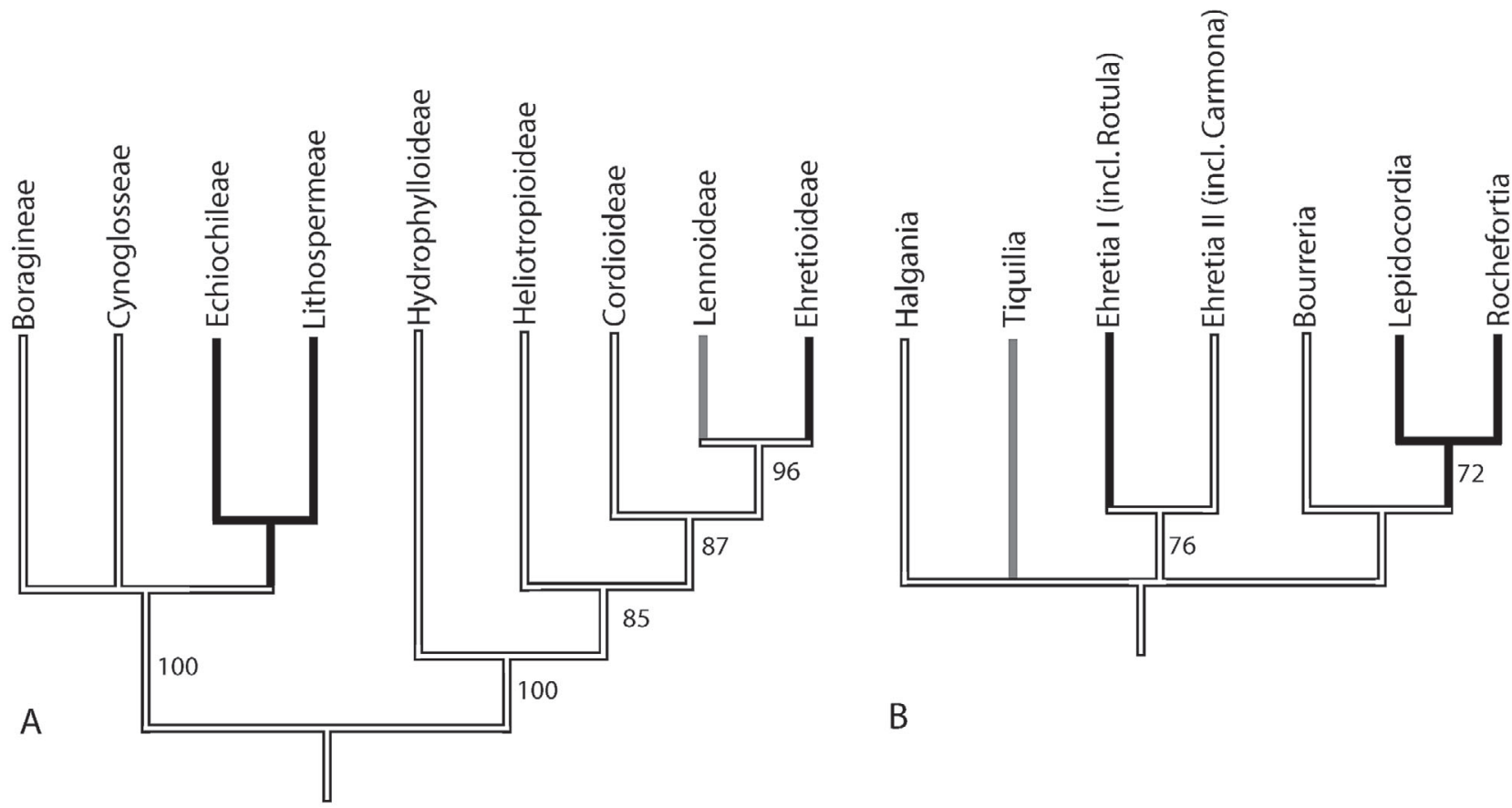

B
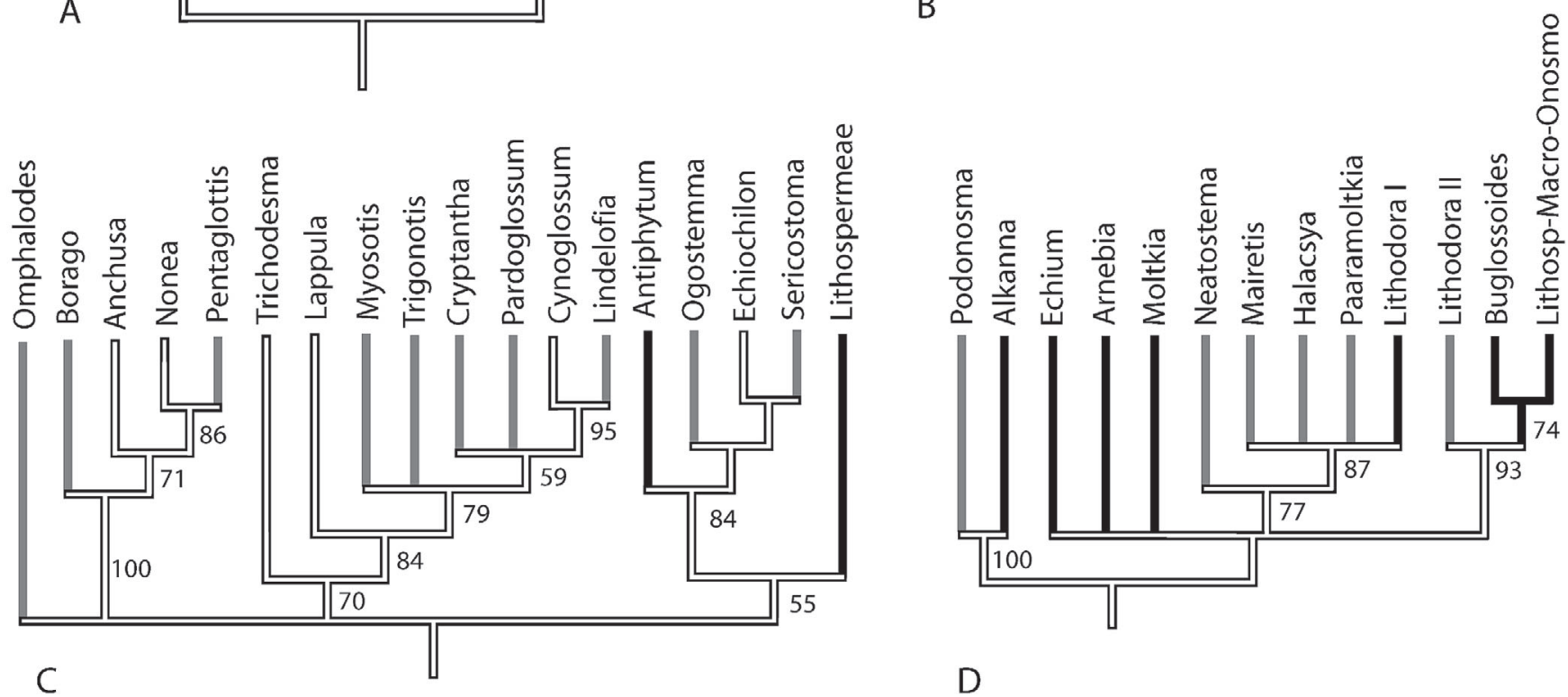

D

Fig. 1. Phylogeny of (A) Boraginaceae, (B) Ehretioideae, (C) Boraginoideae, and (D) Lithospermeae based on Gottschling \& al. (2001), Langström \& Chase (2002), Gottschling (2003), Thomas \& al. (2008). Taxa with non-vestured pits are indicated in white, taxa with vestured pits are in black, taxa in grey are not studied. Numbers on the right of the branches are bootstrap support values to the clade above them (values under $50 \%$ not shown). 
Table 1. Overview of the distribution of vestured pits in Boraginaceae based on data from literature and our observations.

\begin{tabular}{lll}
\hline & Vestured pits & Non-vestured pits \\
\hline Literature & Echium, Rochefortia, Pteleocarpa, Bourreria, He- & Auxemma, Cordia, Ehretia, Heliotropium, Patagonula, \\
& liotropium (Miller, 1977); Lepidocordia, Pteleocarpa & Saccellium, Tournefortia (Miller, 1977); Auxemma, Cor- \\
& (Gottwald, 1982); Cordia (Barajas-Morales, 1981; & dia, Patagonula (Gottwald, 1983); Codon, Cynoglossum, \\
& Gottwald, 1983; Nair \& Mohan Ram, 1989); Echium, & Halgania, Wigandia (Jansen \& al., 2001) \\
& Onosma, Lithodora (Schweingruber, 1990); Echium & \\
& (Jansen \& al., 2001) & \\
Results from this study & Alkanna, Amblynotopsis, Antiphytum, Arnebia, Buglos- & Amsinckia, Anchusa, Argusia, Bourreria, Carmona, \\
& Soides, Echium, Ehretia, Hydrolea, Lepidocordia, & Ceballosia, Codon, Cordia, Cynoglossum, Echiochilon, \\
& Lithodora, Lithospermum, Lobostemon, Moltkia, & Eriodictyon, Halgania, Heliotropium, Hilsenbergia, Lap- \\
& Onosma, Rochefortia Rotula & pula, Mertensia, Messerschmidia, Nama, Nonea, Phacelia, \\
& Selkirkia, Tournefortia, Trichodesma, Wellstedia, Wigandia \\
\hline
\end{tabular}

SEM (Jeol Ltd., Tokyo, Japan) at $15 \mathrm{kV}$. Measurements were carried out on SEM images using ImageJ (http://rsbweb.nih. gov/ij/). All pit dimensions were based on measurements of ten pits.

\section{口ESULTS}

The presence of vestures was associated with bordered vessel pits in 43 species of the following 16 genera: Alkanna, Amblynotopsis, Antiphytum, Arnebia, Buglossoides, Echium, Ehretia, Hydrolea, Lepidocordia, Lithodora, Lithospermum, Lobostemon, Moltkia, Onosma, Rochefortia, and Rotula (Fig. 2B-I; Table 1; Table S1 in the Electronic Supplement). Vestured pits were not observed in 62 species out of 25 genera (Fig. 2A, J-O; Tables 1, S1). When vestured pits were present, the feature was found in all bordered pits of vessel elements across a wood sample.

Vestured pits were mainly found in species belonging to Boraginoideae and Ehretioideae (Fig. 2C-I), but are also found in Hydrolea spinosa (Fig. 2B). No vestures were observed in Wellstedia dinteri (Fig. 2J), Cordioideae (Fig. 2L), and Heliotropioideae (Fig. 2K).

Most vestures were observed as rudimentary, unbranched or weakly branched structures near the outer pit aperture. In general, the vestures pointed into the pit chamber (Fig. 2G-H) or towards the pit aperture (Fig. 2C, I). In some Ehretia species, the vestures formed a dense, compact network obstructing the pit aperture or almost completely filling up the pit chamber (Fig. 2G-H). In most species with vestured vessel pits, vestures were also noticed in bordered pits of tracheids and fibre-tracheids (Table S1). Vestures in these imperforate tracheary elements were always small and unbranched. The mean height of vestures varied from $0.27 \mu \mathrm{m}$ in Amblynotopsis linifolia (M. Martens \& Galeotti) Brand to $0.82 \mu \mathrm{m}$ in Buglossoides arvensis (L.) I.M. Johnst., with a maximum of $1.32 \mu \mathrm{m}$ in Lithospermum afromontanum Weim. The mean thickness varied from $0.21 \mu \mathrm{m}$ in Ehretia amoena Klotzsch to $0.70 \mu \mathrm{m}$ in Echium boissieri Steud. The average pit size or mean horizontal diameter of vessel pits varied from $2.67 \mu \mathrm{m}$ in Rochefortia acanthophora Griseb. to $7.09 \mu \mathrm{m}$ in Anchusa arvensis Tausch. The pit size was tested to be significantly smaller in species with vestured pits than in species with non-vestured pits $(P=$ 0.0073). There was no significant difference between species with and without vestures with respect to the horizontal and vertical diameter of the pit aperture.

\section{DISCUSSION}

The intrafamily distribution of species with vestured pits is restricted to the distantly related Boraginoideae and Ehretioideae (Fig. 1B-D) (Ferguson, 1999; Gottschling \& al., 2001; Langström \& Chase, 2002; Moore \& Jansen, 2006; Luebert $\&$ Wen, 2008). The potential link between Wellstedioideae and Boraginoideae cannot be contradicted, but the absence of vestures in Wellstedioideae does not give extra support for this relationship as well, since most of the subfamilies lack vestures (Stevens, 2001-). Further reseach is needed to elucidate the correct systematic position of Wellstedioideae in the Boraginaceae.

Within the subfamily Boraginoideae, the species with vestured pits mainly belong to the tribe Lithospermeae (Fig. 1C-D) (Langström \& Chase, 2002; Thomas \& al., 2008). Vestured pits are observed in all Lithospermeae species studied. Our study has revealed that the genus Antiphytum, which has been removed to the newly circumscribed tribe Echiochileae (including only Echiochilon and Antiphytum; Langström \& Chase, 2002, Langström \& Oxelman, 2003), has vestured pits, but we observed non-vestured pits in Echiochilon. Since only a single specimen of Antiphytum and Echiochilon was examined in this study, more comprehensive sampling is needed to explore the inconsistent distribution of vestures in Echiochileae. The remaining Boraginoideae genera with non-vestured pits ( $\mathrm{An}$ chusa, Cynoglossum, Nonea, Lappula, Trichodesma) belong to the tribes Boragineae and Cynoglosseae.

When comparing more traditional tribal circumscriptions of Boraginoideae (de Candolle, 1846; Bentham \& Hooker, 1873; Baillon, 1888; Gürke 1893; Al-Shehbaz, 1991; Riedl, 1997; Takhtajan, 1997), it becomes clear that Amsickia and Selkirkia, both lacking vestured pits, were traditionally grouped in Cynoglosseae or in the former Eritrichieae. The genera of Eritrichieae are nowadays included in Cynoglosseae or Echiochileae according to molecular analyses (Langström \& 


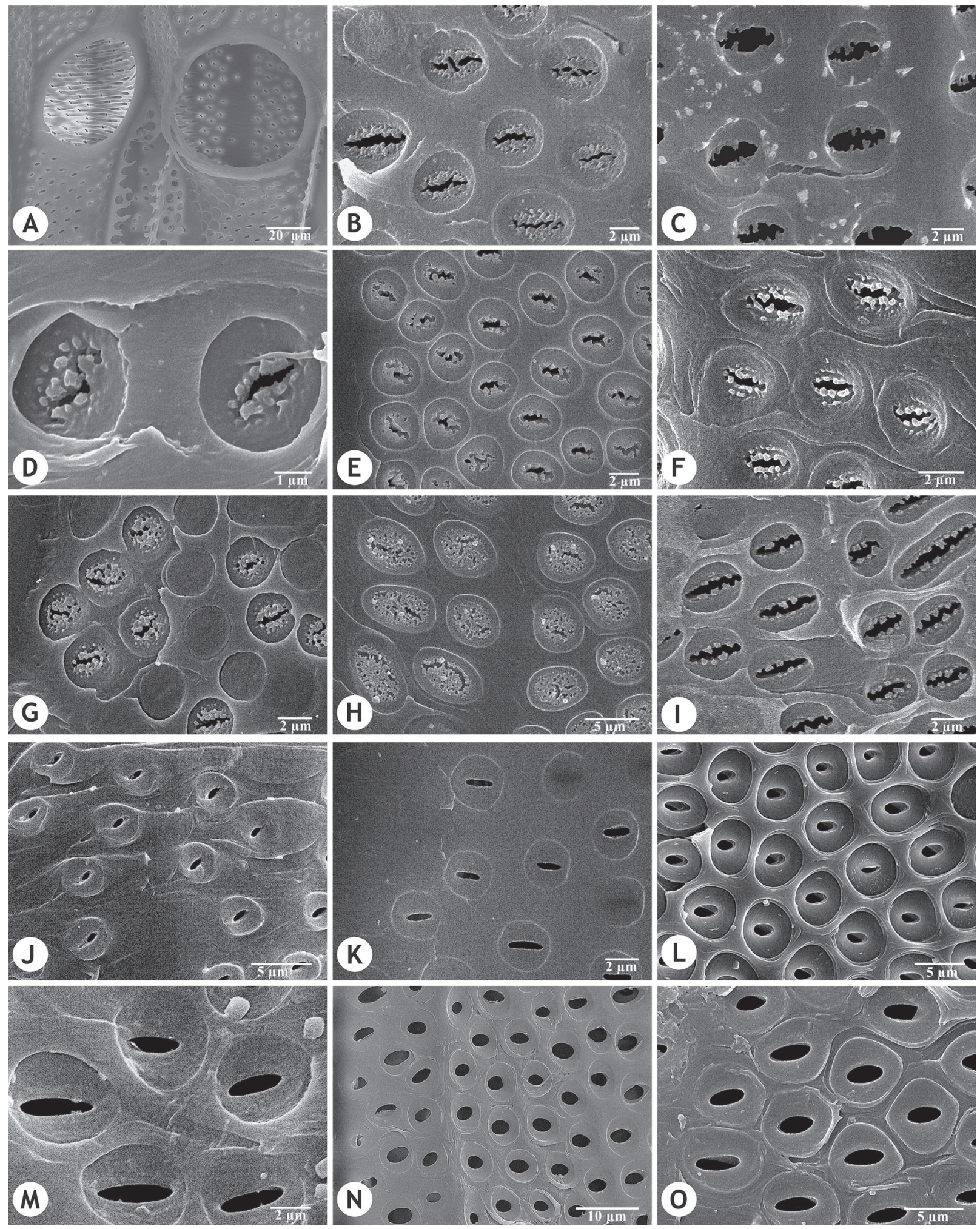

Fig.2. SEM observations of the outer vessel wall with vestured and non-vestured pits in Boraginaceae. A, low magnification of a vessel with nonvestured pits in Cordia scabra Desf.; B, vessel pits with vestured outer pit apertures in Hydrolea spinosa L.; C, vestures in vessel pits in Arnebia hispidissima DC.; D, detail of vestures in vessel pits Alkanna lutea Moris; E, vestured vessel pits in Lepidocordia punctata Ducke; F, distinctly vestured vessel pits in Rochefortia stellata Britton \& P. Wilson; G, vestured vessel pits in Ehretia obtusifolia Hochst. ex DC.; H, vestures form a dense network in the pit chamber of vessel pits in Ehretia laevis Roxb.; I, vestured vessel pits in Rotula aquatica Lour.; J-0, non-vestured vessel pits in (J) Wellstedia dinteri Pilg., (K) Heliotropium calcicola Fernald, (L) Cordia alba Roem. \& Schult., (M) Echiochilon fruticosum Desf., (N) Trichodesma zeylanicum R. Br., (0) Ehretia longiflora Champ. ex Benth. 
Chase, 2002). Likewise, the taxonomic position of Mertensia has frequently been the topic of discussion. This genus was traditionally placed in Lithospermeae or Trignotideae, which are scattered over Cynoglosseae and Echiochileae in the study of Langström \& Chase (2002). The absence of vestured pits in Mertensia, Amsickia, and Selkirkia does not allow us to suggest a position of these genera within either Echiochileae or Cynoglosseae.

The distribution of vestured pits in Ehretioideae is more difficult to explain due to the lack of a well-sampled and robust phylogeny (Fig. 1B) (Gottschling \& Hilger, 2001; Gottschling, 2003). Based on phylogenies by Gottschling \& Hilger (2001) and Gottschling (2003), vestured pits have originated at least once in Ehretioideae, and presumably even twice (Fig. 1B): (1) in the Lepidocordia-Rochefortia clade, and (2) in the Ehretia clade. The close relationship between Lepidocordia and Rochefortia was suggested for the first time by Gottschling (2003) based on dioecy. The presence of vestured pits in these two genera provides an additional morphological character supporting their sister relationship (Fig. 2E-F).

The genus Ehretia has been suggested to be split in two clades (Gottschling \& Hilger, 2001; Fig. 1B). Interestingly, the distribution of vestured pits characterises the group of Ehretia I, including Rotula aquatica Lour. (Fig. 2G-I), while species with non-vestured pits belong to the clade of Ehretia II (Fig. 2O), which comprises Carmona retusa (Vahl.) Masam.

Based on our data, vestured pits show at least two independent origins within Boraginaceae: (1) once in Boraginoideae, i.e., Lithospermeae and Echiochileae sensu Langström \& Chase (2002) (Fig. 1A), and (2) once (or twice) in Ehretioideae, depending on the relationships between the Lepidocordia-Rochefortia clade and Ehretia clade in a more resolved Ehtretioideae phylogeny (Fig. 1B).

The systematic position of the Boraginaceae within asterids is unclear. At the moment Boraginaceae are provisionally placed at the base of the asterids I (APG, 1998, 2003). Molecular data suggest a possible sister relationship either with Lamiales or Solanales (Olmstead \& al., 1999, 2000; Savolainen $\&$ al., 2000; Lundberg, 2001). Since both orders include species with vestured pits, our observations do not provide additional evidence for the taxonomic position of Boraginaceae.

The observations of vestured pits recorded in earlier studies are generally confirmed (Tables 1, S1). Miller (1977) reported the presence of vestures in Heliotropium calcicola Fernald, although he questioned this observation based on the inconsistent occurrence of vestures. Our sample of $H$. calcicola did not show any vestures in vessel pits, suggesting that Miller's (1977) record was an artefact and probably due to extraneous deposits in pit borders. Furthermore, the presence of weakly developed vestures in some Cordia species has been mentioned by various authors (Barajas-Morales, 1981; Gottwald, 1983; Nair \& Mohan Ram, 1989), but we could not observe vestured pits in any of the Cordia species studied (Fig. 1A, L). In our opinion, the earlier records in Cordia were due to misinterpretation of pseudo-vestures (see Bailey, 1933; Gale; 1982, Jansen $\&$ al., 1998). On the other hand, the recording of vestures in Pteleocarpa seems justified (Gottwald, 1982). This genus was shown to be included in Gelsemiaceae (Olmstead \& Ferguson, 2001; APG, 2003), one of the families of the order Gentianales, which is entirely characterized by the uniform presence of vestured pits (Jansen \& Smets, 2000).

The systematic position of Hydrolea within Hydrophylloideae has repeatedly been questioned. Cosner \& al. (1994) and APG $(1998,2003)$ suggested considering the genus as a separate family Hydroleaceae within Solanales. The transfer of the vestured Hydrolea from the non-vestured Hydrophylloideae to Solanales was supported by flower morphology data and is further corroborated by our results (Erbar \& al., 2005). In Solanales, vestured pits have been observed in Montiniaceae and Kaliphoraceae, which are closely related to Hydroleaceae, and some Solanaceae (Jansen \& al., 2001).

Ecological data discussing the distribution of vestured pits within angiosperms are summarized by Jansen \& al. (2004). In general, the highest percentages of species with vestures in vessel pits are found in warm climates with periods of drought, such as tropical seasonal woodlands or deserts, while species with vestured pits are scarce in colder climates. Based on distribution data of the Boraginaceae species studied, species with vestured pits are more abundant in tropical woodlands with a seasonal climate or in subtropical warm temperate climates. Despite our limited sampling and the lack of detailed ecological information on herbarium labels, these findings are in line with the conclusions of Jansen \& al. (2004). Nevertheless, in addition to understanding the distribution of vestured pits as ecological adaptation to environmental conditions, there are clear phylogenetic influences in the family. For example, many of the non-vestured Cordia species are more tropical in distribution than most of the Lithospermeae species that are characterized by vestured pits (Gottschling \& al., 2004; Thomas \& al., 2008).

Differences in horizontal pit diameter between species with and without vestured pits are statistically significant $(P=0.0073)$, suggesting that vestured pits are smaller than non-vestured pits. The same results were found by Wheeler $\&$ al. (2007) by analysing data from the InsideWood database (2004). Consequently, these results show that vestures are less common in large pits compared with medium-sized, small and minute pits. There is convincing evidence that intervessel pit membranes play a major role in cavitation caused by drought stress (Tyree \& Zimmermann, 2002; Choat \& al., 2008). Vestured pits have been suggested to support the pit membrane in a pit pair when deflected by a pressure difference between two neighbouring vessels (Zweypfenning, 1978). Mechanical support of the pit membrane could prevent tearing or rupturing of the pit membrane. Hence, species with vestured pits have been suggested to show higher air-seeding thresholds than species with non-vestured pits, which implies that species with vestured pits have a higher hydraulic safety and are less vulnerable to drought-induced cavitation (Jansen \& al., 2009). Experimental evidence for an increased hydraulic safety has been demonstrated for few Legumes (Choat \& al., 2004; Jansen \& al., 2009). However, functional advantages of vessel pits that are rudimentarily vestured as in most Boraginaceae are unclear and need further research. 


\section{ACKNOWLEDGEMENTS}

We thank the curators of following institutions for the supply of material: BR, MADw, Tw, Uw, and USw. Research at the Laboratory of Plant Systematics is supported by research grants from the K.U. Leuven (OT/05/35) and the Fund for Scientific Research-Flanders (Belgium) (G.0268.04 and G.0250.05). FL is a postdoctoral fellow of the Fund for Scientific Research-Flanders (Belgium).

\section{LITERATURE CITED}

Al-Shehbaz, I. 1991. The genera of Boraginaceae in the southeastern United States. J. Arnold Arbor. Suppl. Ser. 1: 1-169.

APG (Angiosperm Phylogeny Group). 1998. An ordinal classification for the families of flowering plants. Ann. Missouri Bot. Gard. 85: 531-553.

APG (Angiosperm Phylogeny Group). 2003. An update of the Angiosperm Phylogeny Group classification for the orders and families of flowering plants: APG II. Bot. J. Linn. Soc. 141: 399-436.

Bailey, I.W. 1933. The cambium and its derivative tissues: VIII, Structure, distribution, and diagnostic significance of vestured pits in dicotyledons. J. Arnold Arbor. 14: 259-273.

Baillon, H. 1888. Boraginacées. Pp. 343-402 in: Baillon, H. (ed.), Histoire des plantes. Paris: Librairie Hachette \& Cie.

Barajas-Morales, J. 1981. Description and notes on the wood anatomy of Boraginaceae from western Mexico. I.A.W.A. Bull. 2: 61-67.

Bentham, G. \& Hooker, J.D 1873. Genera plantarum, vol. 2. London: Reeve.

Choat, B., Cobb, A.R. \& Jansen, S. 2008. Structure and function of bordered pits: New discoveries and impacts on whole-plant hydraulic function. New Phytol. 177: 608-626.

Choat, B., Jansen, S., Zwieniecki, M.A., Smets, E. \& Holbrook, N.M. 2004. Changes in pit membrane porosity due to deflection and stretching: The role of vestured pits. J. Exp. Bot. 55: 1569-1575.

Cosner, M.E., Jansen, R.K. \& Lammers, T.G. 1994. Phylogenetic relationships in the Campanulales based on $r b c L$ sequences. $P l$. Syst. Evol. 190: 79-95.

Craven, L.A. 2005. Malesian and Australian Tournefortia transferred to Heliotropium and notes on delimitation of Boraginaceae. Blumea 50: 375-381

Candolle, A. de. 1846. Borrage. Pp. 1-178 in: Candolle, A. de (ed.), Prodromus systematis naturalis regni vegetabilis, vol. 10. Paris: Fortin, Masson \& soc.

Erbar, C., Pormbski, S. \& Leins, P. 2005 Contributions of the systematic position of Hydrolea (Hydroleaceae) based on floral development. Pl. Syst. Evol. 252: 71-83.

Exley, R.R., Butterfield, B.G. \& Meylan, B.A. 1974. Preparation of wood specimens for the scanning electron microscope. J. Microscopy 101: 21-30.

Ferguson, D.M. 1999. Phylogenetic analysis and relationships in Hydrophyllaceae base on $n d h F$ sequence data. Syst. Bot. 23: 253-268.

Gale, R. 1982 Some pitfalls in wood identification, with reference to Nothofagus. I.A.W.A. Bull. 3: 179-184.

Gottschling, M. 2003. Phylogenetic analysis of selected Boraginales. Dissertation, Free University of Berlin. http://www.diss.fu-berlin .de/diss/receive/FUDISS thesis 000000001181.

Gottschling, M., Diane, N., Hilger, ing hypotheses on disjunctions present in the primary woody Boraginales: Ehretiacea, Cordiaceae, and Heliotropiaceae, inferred from ITS1 sequence data. Int. J. Pl. Sci. 165 (Suppl.): S123-S135.

Gottschling, M. \& Hilger, H.H. 2001. Phylogenetic analysis and character evolution of Ehretia and Bourreria (Ehretiaceae, Boraginales) and their allies based on ITS1 sequences. Bot. Jahrb. Syst. 123: 249-268.
Gottschling, M., Hilger, H.H., Wolf, M. \& Diane, N. 2001. Secondary structure of the ITS1 transcript and its application in a reconstruction of the phylogeny of Boraginales. Pl. Biol. 3: 629-636.

Gottwald, H. 1982. First description of the wood anatomy of Antrophora, Lepidocordia and Pteleocarpa (Boraginaceae). I.A.W.A. Bull. 3: 161-165.

Gottwald, H. 1983. Wood anatomical studies of Boraginaceae (s.1.): 1, Cordioideae. I.A.W.A. Bull. 4: 161-178.

Gürke, M. 1893. Boraginaceae. In: Engler, A. \& Prantl, K. (eds.), Die natürlichen Pflanzenfamilien, vol. 4 (3a). Leipzig: Engelmann.

Herendeen, P.S. 2000. Structural evolution in the Caesalpinioideae (Leguminosae). Pp. 45-64 in: Heredeen, P.S. \& Bruneau, A. (eds.), Advances in legume systematics, vol. 9. Kew: Royal Botanic Gardens.

InsideWood. 2004-. http://insidewood.lib.ncsu.edu/search. Accessed 21 Oct. 2008.

Jansen, S., Baas, P., Gasson, P., Lens, F. \& Smets, E. 2004. Variation in xylem structure from tropics to tundra: Evidence for vestured pits. Proc. Natl. Acad. Sci. U.S.A. 101: 8833-8837.

Jansen, S., Baas, P. \& Smets, E. 2001. Vestured pits: Their occurrence and systematic importance in eudicots. Taxon 50: 135-167.

Jansen, S., Choat, B. \& Pletsers, A. 2009. Morphological variation of intervessel pit membranes and implications to xylem function in angiosperms. Amer. J. Bot. 96: 409-412.

Jansen, S., Pletsers, A., Rabaey, D. \& Lens, F. 2008. Vestured pits: A diagnostic character in secondary xylem of Myrtales. J. Trop. Forest Sci. 20: 147-155.

Jansen, S. \& Smets, E. 2000. Morphology, distribution, and systematic importance of vestures in Gentianales. Pp. 277-296 in: Nordenstam, B., El-Ghazaly, G. \& Kassas, M. (eds.), Plant systematics for the 21st century. Wenner-Gren International Series, vol. 77. London: Portland Press.

Jansen, S., Smets, E. \& Baas, P. 1998. Vestures in woody plants: A review. I.A.W.A. J. 19: 347-382.

Johnston, I.M. 1950. Studies in the Boraginaceae: XIX, A noteworthy species from tropical America. J. Arnold Arbor. 31: 172-187.

Johnston, I.M. 1951. Studies in Boraginaceae: XX, Representatives of three subfamilies in eastern Asia. J. Arnold Arbor. 32: 1-26, 99-122.

Langström, E. \& Chase, M.W. 2002. Tribes of Boraginoideae (Boraginaceae) and placement of Antiphytum, Echiochilon, Ogastemma, and Sericostoma: A phylogenetic analysis based on atpB plastid DNA sequence data. Pl. Syst. Evol. 234: 137-153.

Langström, E. \& Oxelman, B. 2003. Phylogeny of Echiochilon (Echiochileae, Boraginaceae) based on ITS sequences and morphology. Taxon 52: 725-735.

Lens, F., Endress, M.E., Baas, P., Jansen, S. \& Smets, E. 2008. Wood anatomy of Rauvolfioideae (Apocynaceae): A search for meaningful non-DNA characters at the tribal level. Amer. J. Bot. 95: 1199-1215.

Luebert, F. \& Wen, J. 2008. Phylogenetic analysis and evolutionary diversification of Heliotropium sect. Cochranea (Heliotropiaceae) in the Atacama Desert. Syst. Bot. 33: 390-402.

Lundberg, J. 2001. A well resolved and supported phylogeny of Euasterids II based on a Bayesian inference, with special emphasis on Escalloniaceae and other incertae sedis. Chapter V in: Lundberg, J., Phylogenetic studies in the euasterids II with particular reference to Asterales and Escalloniaceae. Uppsala: Acta Universitatis Upsaliensis.

Mabberley, D.J. 2008. Mabberley's plant-book, 3rd ed. Cambridge: Cambridge Univ. Press.

Miller, R.B. 1977. Vestured pits in Boraginaceae. I.A.W.A. Bull. 3: 43-48.

Miller, J.S. 2003. Classification of Boraginaceae subfam. Ehretioideae: Resurrection of the genus Hilsenbergia Tausch ex Meisn. Adansonia 25: 151-189.

Moore, J.M. \& Jansen, R.K. 2006. Molecular evidence for the age, origin, and evolutionary history of the American desert plant genus Tiquilia (Boraginaceae). Molec. Phylog. Evol. 39: 668-687. 
Nair, M.N.B. \& Mohan Ram, H.Y. 1989. Vestured pits and vestured vessel member walls in some Indian dicotyledonous woods. Bot. J. Linn. Soc. 100: 323-336.

Ohtani, J. \& Ishida, S. 1976. Study on the pits of wood cells using scanning electron microscopy: 5, Vestured pits in Japanese dicotyledonous woods. Res. Bull. Coll. Exp. Forests Hokkaido Univ. 33: 407-435.

Olmstead, R.G. \& Ferguson, D. 2001. A molecular phylogeny of the Boraginaceae-Hydrophyllaceae. In: Botany 2001: Abstracts. Columbus, Ohio: Botanical Society of America.

Olmstead, R.G., Kim, K.J., Jansen, R.K. \& Wagstaff, S.J. 2000. The phylogeny of the Asteridae sensu lato based on chloroplast $n d h F$ gene sequence. Molec. Phylog. Evol. 16: 96-112.

Olmstead, R.G., Sweere, J.A., Spangler, R.E., Bohs, L. \& Palmer, J.D. 1999. Phylogeny and provisional classification of the Solanaceae based on chloroplast DNA. Pp. 111-137 in: Nee, M., Symon, D., Lester, R.N. \& Jessop, J.P. (eds.), Solanaceae IV: Advances in biology and utilization. Kew: Royal Botanic Gardens.

Pilger, R. 1912. Die Gattung Wellstedia in Südwestafrika. Bot. Jahrb. Syst. 46: 558-561.

Retief, E. \& Van Wyk, A.E. 2005. Boraginaceae: Codonoideae, a new subfamily based on Codon. Bothalia 35: 78-80.

Riedl, H. 1997. Boraginaceae. Pp. 43-168 in: Kalkman, C., Noteboom, H.P., de Wilde, W.J., Kirkup, D.W. \& Stevens, P.F. (eds.), Flora malesiana Series 1: Seed plants, vol. 13. Leiden: Rijksherbarium.

Savolainen, V., Chase, M.W., Hoot, S.B., Morton, C.M., Soltis, D.E.,
Bayer, C., Fay, M.F., de Bruijn, A.Y., Sullivan, S. \& Qui, Y.L. 2000. Phylogenetics of flowering plants based on combined analysis of plastid $a t p B$ and $r b c L$ sequences. Syst. Biol. 49: 306-362.

Schweingruber, G. 1990. Anatomie europäischer Hölzer. Anatomy of European woods. Bern \& Stuttgart: Haupt.

Scurfield, G., Silva S.R. \& Ingle, H.D. 1970. Vessel wall structure: An investigation using scanning electron microscopy. Austral. J. Bot. 18: 301-312.

Stevens, P.F. 2001-. Angiosperm Phylogeny Website, version 9, June 2008. http://www.mobot.org/MOBOT/research/APweb/.

Takhtajan, A.L. 1997. Diversity and classification of flowering plants. New York: Columbia Univ. Press.

Thomas, D.C., Weigend, M. \& Hilger H.H. 2008. Phylogeny and systematics of Lithodora (Boraginaceae-Lithospermeae) and its affinities to the monotypic genera Mairetis, Halacsya and Paramoltkia based on ITS1 and $\operatorname{trn} L_{\mathrm{UAA}}$-sequence data and morphology. Taxon 57: 79-97.

Tyree, M.T. \& Zimmerman, M.H. 2002. Xylem structure and the ascent of sap, 2nd ed. New York: Springer.

Van Vliet, G.J.C.M. 1978. Vestured pits in Combretaceae and allied families. Acta Bot. Neerl. 27: 273-285.

Wheeler, E., Baas, P. \& Rodgers S. 2007. Variation in dicot wood anatomy: A global analysis based on the InsideWood database. I.A.W.A. J. 28: 229-258.

Zweypfenning, R.C.V.J. 1978. A hypothesis on the function of vestured pits. I.A.W.A. Bull. 1: 13-15. 